\title{
TASK 1.13 - DATA COLLECTION AND DATABASE DEVELOPMENT FOR CLEAN COAL TECHNOLOGY BY-PRODUCT CHARACTERISTICS AND MANAGEMENT PRACTICES
}

Final Topical Report

for the period January 1, 1997, through June 30, 1998

Prepared for:

Federal Energy Technology Center

AAD Document Control

U.S. Department of Energy

PO Box 10940, MS 921-143

Pittsburgh, PA 15236

Cooperative Agreement No. DE-FC21-93MC30097-33

Performance Monitor: Scott Renninger

Prepared by:

Debra F. Pflughoeft-Hassett

Energy \& Environmental Research Center

University of North Dakota

PO Box 9018

Grand Forks, ND 58202-9018

98-EERC-10-13

October 1998 


\section{DOE DISCLAIMER}

This report was prepared as an account of work sponsored by an agency of the United States Government. Neither the United States Government, nor any agency thereof, nor any of their employees makes any warranty, express or implied, or assumes any legal liability or responsibility for the accuracy, completeness, or usefulness of any information, apparatus, product, or process disclosed or represents that its use would not infringe privately owned rights. Reference herein to any specific commercial product, process, or service by trade name, trademark, manufacturer, or otherwise does not necessarily constitute or imply its endorsement, recommendation, or favoring by the United States Government or any agency thereof. The views and opinions of authors expressed herein do not necessarily state or reflect those of the United States Government or any agency thereof.

Available to the public from the National Technical Information Service, U.S. Department of Commerce, 5285 Port Royal Road, Springfield, VA 22161; phone orders accepted at (703) 487-4650.

\section{ACKNOWLEDGMENT}

This report was prepared with the support of the U.S. Department of Energy (DOE) Federal Energy Technology Center, Cooperative Agreement No. DE-FC21-93MC30097. However, any opinions, findings, conclusions, or recommendations expressed herein are those of the author(s) and do not necessarily reflect the views of DOE.

\section{EERC DISCLAIMER}

LEGAL NOTICE This research report was prepared by the Energy \& Environmental Research Center (EERC), an agency of the University of North Dakota, as an account of work sponsored by DOE. Because of the research nature of the work performed, neither the EERC nor any of its employees makes any warranty, express or implied, or assumes any legal liability or responsibility for the accuracy, completeness, or usefulness of any information, apparatus, product, or process disclosed or represents that its use would not infringe privately owned rights. Reference herein to any specific commercial product, process, or service by trade name, trademark, manufacturer, or otherwise does not necessarily constitute or imply its endorsement or recommendation by the EERC. 


\section{TABLE OF CONTENTS}

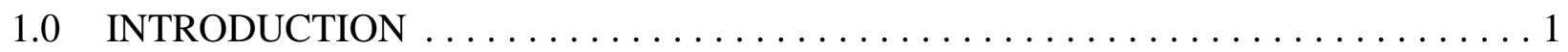

2.0 GOALS AND OBJECTIVES $\ldots \ldots \ldots \ldots \ldots \ldots \ldots \ldots \ldots \ldots \ldots \ldots \ldots$

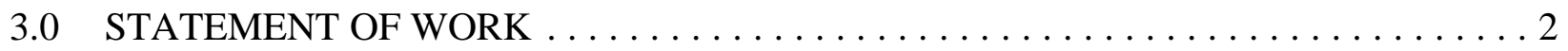

3.1 Subtask 1 - Collect Data on PFBC and Gasification Systems . . . . . . . . . . 2

3.2 Subtask 2 - Assemble CCT By-Product Management Information . . . . . . . . . . 2

3.3 Subtask 3 - Finalize Energy \& Environmental Research Center (EERC) Report of Barriers to CCB Utilization . . . . . . . . . . . . . . . . . 2

3.4 Subtask 4 - Develop a CCT By-Product Workshop $\ldots \ldots \ldots \ldots \ldots \ldots \ldots \ldots 2$

4.0 ACCOMPLISHMENTS . . . . . . . . . . . . . . . . . . . . . 3

4.1 Preparation of the "IGCC and PFBC By-Products: Generation, Characteristics,

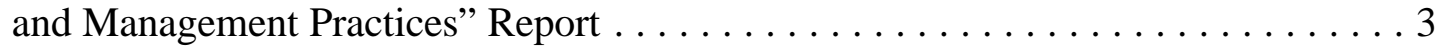

4.2 Preparation of the "Barriers to the Increased Utilization of Coal Combustion/Desulfurization Byproducts by Government and Commercial Sectors - Update 1998 " Report . . . . . . . . . . . . . . . . . . . . 4

4.3 Assembly of Information for DOE Environmental Workshop . . . . . . . . . . 4

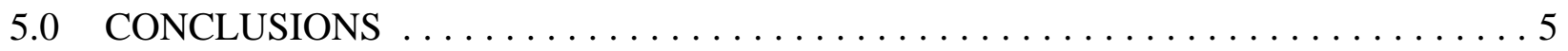

5.1 "IGCC and PFBC By-Products: Generation, Characteristics, and Management

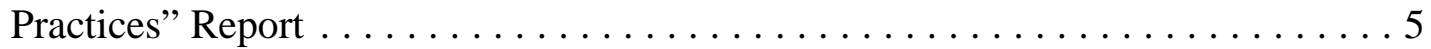

5.2 "Barriers to the Increased Utilization of Coal Combustion/Desulfurization Byproducts by Government and Commercial Sectors - Update 1998" Report . . . 5

5.3 Assembly of Information for DOE Environmental Workshop $\ldots \ldots \ldots \ldots \ldots$

DRAFT TABLE OF CONTENTS FOR “BARRIERS TO THE INCREASED UTILIZATION OF COAL COMBUSTION/DESULFURIZATION BYPRODUCTS BY GOVERNMENT AND COMMERCIAL SECTORS - UPDATE $1998 " \ldots \ldots \ldots \ldots \ldots \ldots \ldots \ldots \ldots \ldots \ldots \ldots \ldots \ldots \ldots$ Appendix A 


\section{TASK 1.13 - DATA COLLECTION AND DATABASE DEVELOPMENT FOR CLEAN COAL TECHNOLOGY BY-PRODUCT CHARACTERISTICS AND MANAGEMENT PRACTICES}

\subsection{INTRODUCTION}

U.S. Department of Energy Federal Energy Technology Center-Morgantown (DOE FETC) efforts in the areas of fossil fuels and clean coal technology (CCT) have included involvement with both conventional and advanced process coal conversion by-products. In 1993, DOE submitted a Report to Congress (RTC) on "Barriers to the Increased Utilization of Coal Combustion/Desulfurization Byproducts by Governmental and Commercial Sectors," which provided an outline of activities to remove the barriers identified in the report. DOE charged itself with participation in this process, and the work proposed in this document facilitates DOE's response to its own recommendations for action. The work reflects DOE's commitment to the coal combustion by-product (CCB) industry, to the advancement of clean coal technology, and to cooperation with other government agencies.

Information from DOE projects and commercial endeavors in fluidized-bed combustion (FBC) and coal gasification is the focus of this task. The primary goal is to provide an easily accessible compilation of characterization information on the by-products from these processes to government agencies and industry to facilitate sound regulatory and management decisions. Additional written documentation will facilitate the preparation of an updated final version of background information collected for DOE in preparation of the RTC on barriers to CCB utilization.

The information assembled is valuable to the Environmental Protection Agency (EPA) in its upcoming decision on the waste status of FBC by-products and was submitted to EPA in September 1997. This effort facilitates interaction between DOE and industry regarding input to EPA. The effort of DOE FETC to provide this type of information to EPA is consistent with the recommendation in the DOE RTC on ash barriers, that a determination placing CCT by-products under RCRA (Resource Conservation and Recovery Act) Subtitle D for solid wastes is needed if these materials are to be utilized. Several DOE projects have already investigated utilization of these materials, so this is an opportunity to give this information the emphasis it deserves.

\subsection{GOALS AND OBJECTIVES}

The primary goal of this task is to provide an easily accessible compilation of characterization information on CCT by-products to government agencies and industry to facilitate sound regulatory and management decisions. Supporting objectives are to 1) fully utilize information from previous DOE projects, 2) coordinate with industry and other research groups, 3 ) focus on by-products from pressurized fluidized-bed combustion (PFBC) and gasification, and 4) provide information relevant to the EPA evaluation criteria for the decision on the RCRA status of FBC by-products. 


\subsection{STATEMENT OF WORK}

Details of the statement of work follow.

\subsection{Subtask 1 - Collect Data on PFBC and Gasification Systems}

Through literature, industrial and government contacts, and the research community, additional by-product and process data on PFBC and gasification systems will be collected and added to the database. Projects supported by DOE are expected to provide significant data for this subtask. Contacts and sources used in previous EERC efforts will be used, but it is anticipated that additional contacts, sources, and information will need to be developed through the performance of a literature search, trade associations, and personal contacts at utility and industrial plants with these systems in place.

\subsection{Subtask 2 - Assemble CCT By-Product Management Information}

CCT by-products are relatively new to the CCB utilization industry, so the information collected in Subtask 1 may not include well-developed by-product management information. A specific effort will be made to collect and include management options for PFBC and gasification by-products. Using all contacts and sources developed in the previous subtask, these options will be identified with the intent to collect specific information on by-product utilization examples, demonstrations, and commercial applications.

\subsection{Subtask 3 - Finalize Energy \& Environmental Research Center (EERC) Report of Barriers to CCB Utilization}

The EERC assembled comprehensive information on CCB production, characteristics, and management options at the request of FETC prior to the submission of DOE's RTC on "Barriers to the Increased Utilization of Coal Combustion/Desulfurization Byproducts by Governmental and Commercial Sectors." The draft EERC report focuses on utilization of CCBs and will have broad applicability for regulatory agencies and CCB users. This report requires revision prior to its being published by FETC, and these revisions will be accomplished according to review comments previously received from FETC. Since this report was originally prepared in 1993, it is also proposed to add an update to the report summarizing 1) current production and management statistics, 2) regulatory and legislative activities involving CCBs, 3) impacts of technology changes, and 4) new utilization options and standards and specifications.

\subsection{Subtask 4 - Develop a CCT By-Product Workshop}

Following the collection and submittal of the information on CCT by-products, the EERC will work with DOE and industry to develop a workshop designed to inform regulatory agencies and potential users about the properties and management options for CCT by-products. 


\subsection{ACCOMPLISHMENTS}

This subtask has been under way since late October 1996. The activities in this subtask have been focused on data gathering for and preparation of two separate reports:

- "IGCC and PFBC By-Products: Generation, Characteristics, and Management Practices"

- "Barriers to the Increased Utilization of Coal Combustion/Desulfurization Byproducts by Government and Commercial Sectors - Update 1998"

Work also included assembly of information on CCT technology by-products to be used in the development of a workshop that DOE or DOE contractors could present to state environmental departments.

\subsection{Preparation of the "IGCC and PFBC By-Products: Generation, Characteristics, and Management Practices" Report}

In order to prepare this report, the EERC initially collected and reviewed technical documentation on the two CCT technologies of interest, PFBC and IGCC (integrated gasification combined cycle), and the associated by-products. That information was supplemented by information gained by the DOE Performance Monitor and the EERC Principal Investigator during a visit to one of the DOE-industry-funded commercial-scale IGCC projects in Florida. Information on the IGCC process and by-product management was provided by plant personnel during a tour of the plant site. Formal reports of process data and by-product data were obtained from two IGCC commercial-scale projects. Limited information was obtained through public documents on a third IGCC commercial-scale project. Extensive by-product characterization and management information was obtained on the Tidd Station PFBC commercial-scale demonstration project.

The EERC Principal Investigator met with EPA and industry groups. EPA agreed to review the information on IGCC and PFBC by-products, with the request that a section of the report provide background information on these emerging technologies and that the commercial potential of these technologies be discussed in the report. Using the information collected from industry, DOE, and literature, the draft report to EPA was prepared and submitted to EPA for initial review on July 31, 1997. Copies of the draft report were also sent to DOE and industry representatives, who provided review comments. The final version of the document incorporated changes based on review comments, and a hard copy and an electronic copy of the report were submitted to EPA on September 30, 1997, which was the EPA deadline for submission of information to be reviewed for its determination. The report was also submitted to DOE. Unfortunately, full-scale by-product information was unavailable from two of the IGCC projects at the time of submission of that report. 


\subsection{Preparation of the "Barriers to the Increased Utilization of Coal Combustion/Desulfurization Byproducts by Government and Commercial Sectors - Update 1998” Report}

Following negotiations with the DOE Performance Monitor, it was decided to prepare a revision of the EERC draft "Barriers Report" that was submitted in October 1993. The revised report outline was developed to include a greater emphasis on coal use technologies, including CCT, by-product management options, and changes in barriers since the DOE RTC on that subject submitted by DOE in July 1994. A copy of the Table of Contents of the revised report is included in Appendix A.

Using recent documentation, the report was rewritten to meet current DOE objectives. Several industrial groups were contacted for input to the report in order to properly reflect activities initiated by industry and the viewpoint of industry relative to progress in removing barriers to CCB utilization. A draft report was developed, reviewed by both industry and DOE, and a final version of the report was submitted to DOE for publication.

\subsection{Assembly of Information for DOE Environmental Workshop}

The EERC worked with DOE contractors at Radian International to develop a joint technology transfer effort for state regulators on the issues related to CCT by-products. The collaborative effort with Radian International focused on two primary areas: 1) identifying state agency contacts to be included in the Radian database and 2) developing a presentation to be given at individual state agencies.

The state agency presentation was planned to be accomplished in a 1.5- to 2-hour time frame, including opportunities for questions and discussion. An outline was developed for the presentation:

1) Basic information on coal conversion processes and types of by-products

2) Summary of DOE research

3) Summary of current regulatory framework

4) A computer tour of related Web sites

5) Discussion period

Site visits were planned to include agencies in states from four primary regions in the United States: the West, Midwest, Southeast, and Northeast. Selection of specific states is still pending; however, it was determined to select states that are considered progressive as well as states that are still on the learning curve, so that the presentation team can bring comments and expertise from one agency to others. It is typical that state agencies within a region tend to be aware of actions within their region, and these presentations can potentially facilitate the implementation regulations that remove barriers to increase $\mathrm{CCB}$ utilization in proven applications.

The EERC provided information primarily on IGCC and PFBC by-product characteristics and management options, environmental testing, and information on the western U.S. CCB 
industry and state agency concerns. The EERC Principal Investigator met with DOE representatives, Radian, and DOE invitees to present a "dry run" of the workshop and discuss changes to the format and information.

\subsection{CONCLUSIONS}

\section{1 'IGCC and PFBC By-Products: Generation, Characteristics, and Management Practices" Report}

The time frame for the EPA determination on the RCRA status of FBC by-products has been extended by a period of 1 year to April 1999. This provides an opportunity for DOE to respond to EPA with additional information from the two IGCC projects that are still assembling the required data during the anticipated comment period. In order to take advantage of the information already submitted, it is recommended that DOE follow up on the EPA waste determination and provide comments during the EPA comment period. In follow-up conversations with Roy Dowd at the Wabash River Coal Gasification Repowering Project and Sherry Dawes at the Piñon Pine IGCC Power Plant, it was indicated that the required information will become available prior to the scheduled EPA decision late in 1998. In fact, the projected schedule for each of the IGCC projects would allow DOE to submit that information to EPA during the comment period that EPA will provide to industry and others prior to making its final determination. It is anticipated that the comment period will be scheduled for mid- to late 1998. Dennis Ruddy, the EPA staff member responsible for this determination, has indicated an interest in obtaining the remaining information on full-scale IGCC by-product characteristics and management.

\section{2 "Barriers to the Increased Utilization of Coal Combustion/Desulfurization Byproducts by Government and Commercial Sectors - Update 1998” Report}

The following conclusions were presented in the revised "Barriers" report.

- Joint efforts by industry and government focused on meeting RTC recommendations for reduction/removal of barriers have met with some success. The most notable of these is the changes in regulations related to CCB utilization by individual states. Regionally or nationally consistent state regulation of $\mathrm{CCB}$ utilization would further reduce regulatory barriers.

- Technology changes will continue to be driven by the Clean Air Act Amendments (CAAA), and emission control technologies are expected to continue to impact the type and properties of CCBs generated at a given facility. As a result, continued RD\&D (research, development, and demonstration) will be needed to learn how to utilize new and changing CCBs in environmentally safe, technically sound, and economically advantageous ways. CCT CCBs offer a new challenge because of the high volumes expected to be generated and the different characteristics of these CCBs as compared to conventional CCBs. 
- Industry and government have developed the RD\&D infrastructure to address the technical aspects of developing and testing new CCB utilization applications, but this work as well as constant quality control/quality assurance testing needs to be continued to address both industrywide issues and issues related to specific materials, regions, or users.

- Scrutiny by environmental groups and the public will continue to provide environmental and technical challenges to the CCB industry. It is anticipated that the use of CCBs in mining applications, agriculture, structural fills, and other land applications will continue to be controversial and require technical and environmental information to be developed and reported. The best use of this information will be in the development of regulations specifically addressing the use of CCBs in these types of CCB applications.

- The development of Federal Procurement Guidelines under Executive Order 12873, entitled "Federal Acquisition, Recycling and Waste Prevention," in October 1993 was a positive step toward getting CCBs accepted in the marketplace. Industry needs to continue to work with EPA to develop additional Procurement Guidelines for products containing CCBs and can take advantage of existing guidelines to encourage the use of $\mathrm{CCBs}$ in high-profile projects.

- Limited progress has been made toward the reduction/removal of barriers to the increased utilization of CCBs; however, further progress can only be made if there is an increased financial and technical priority of CCB utilization by industry and government. The framework for this has been set by the successful cooperation of industry and government, with DOE taking a lead role on the government side. Cooperation should continue, with DOE continuing its lead established in the RTC. It is clear that the RTC continues to have validity toward the barriers to increased CCB utilization and continues to provide guidance to industry and government, including DOE itself.

\subsection{Assembly of Information for DOE Environmental Workshop}

While this effort continues through Radian Corporation, the input provided by the EERC resulted in the following conclusions:

- Individual presentations for state regulatory agency staff need to be well planned because the level of familiarity with CCBs by agency representatives varies widely from state to state.

- Options for effectively reaching state regulatory agencies need continuing evaluation. One-on-one contact is anticipated to be the best way to make a high-profile impression on this group, but it is costly and time consuming. Several of the DOE efforts to provide information electronically through the Internet appear to have high value in reaching this group. Technical information, such as information databases as developed by DOE, can be readily presented and made most useful through this medium. 


\section{TABLE OF CONTENTS FOR "BARRIERS TO THE INCREASED UTILIZATION OF COAL COMBUSTION/DESULFURIZATION BYPRODUCTS BY GOVERNMENT AND COMMERCIAL SECTORS - UPDATE 1998"}




\section{TABLE OF CONTENTS}

LIST OF FIGURES

LIST OF TABLES

ACKNOWLEDGMENTS

LIST OF ACRONYMS

EXECUTIVE SUMMARY

1.0 INTRODUCTION

1.1 DOE's Report to Congress

1.1.1 Background

1.1.2 Barriers identified in DOE's RTC

1.1.3 Summary of recommendations made in the RTC

1.2 Summary of Government and Industry Responses to the DOE RTC

2.0 BACKGROUND

2.1 Terminology and Definition .

2.2 U.S. Energy Production from Coal

2.3 U.S. Utility Industry - Coal Use Technologies

2.3.1 Conventional Combustion Systems

2.3.2 Fluidized-Bed Combustion

2.3.3 Coal Gasification

2.3.3.1 Fixed-Bed Gasifiers

2.3.3.2 Integrated Gasification Combined Cycle

2.3.4 Slagging Combustors and Direct-Fired Gas Turbines

2.3.5 Externally Fired Combined Cycle Systems

3.0 CCB PRODUCTION AND MANAGEMENT

3.1 CCB Production

3.1.1 Current Production of Conventional CCBs

3.1.2 Future Production of Conventional CCBs

3.1.3 Advanced Coal Use Technologies - Byproduct Production and

Characteristics

3.1.4 CCB Beneficiation

3.2 CCB Management

3.2.1 Factors Impacting CCB Management Decisions

3.2.1.1 Economic Factors

3.2.1.2 Environmental, Regulatory, and Legal Factors

3.2.1.3 Operational factors

3.2.2 Disposal of CCBs 
3.2.3 Utilization of CCBs

3.2.3.1 Brief History of CCB Use in the U.S.

3.2.3.2

3.2.3.3

Current Status of CCB Utilization . .

CCB Utilization Applications - Technical Summaries

4.0 REVIEW OF BARRIERS TO CCB UTILIZATION

4.1 Review of Barriers Reported in the Literature - Prior to the DOE RTC

4.2 Institutional Barriers

4.2.1 Economics

4.2.2 Marketing

4.2.3 Environmental and Public Perception

4.2.4 Technical Barriers

4.2.5 Education and Attitude

4.3 Regulatory Barriers

4.3.1 Federal Regulations Applying to Coal By-Products

4.3.2 State Regulation of CCBs

4.3.2.1 Pennsylvania

4.3.2.2 Texas

4.4 Legal Barriers

4.5 Recommendations Made to Remove Barriers

4.5.1 Recommendations Made by Industry

4.5.2 Recommendations Made in DOE's RTC

4.5.2.1 Criteria for Recommendations

4.5.2.2 Recommendations for Federal Government Actions

4.5.2.3 State Government and Private Sector Actions

4.6 Responses to Recommendations - 1993 to Present

4.6.1 Industrial Actions

4.6.1.1 Standards Development

4.6.1.2 Industry Sponsored RD\&D Efforts

4.6.1.3 Industry Sponsored Technology Transfer Efforts

4.6.1.4 Lobbying and Review ...

4.6.2 Government Actions responding to recommendations in RTC

4.6.2.1 EPA Determination on RCRA Status of CCBs

4.6.2.2 Department of Energy Report to Congress

4.6.2.3 DOE Activities Relating to RTC Recommendations

4.6.2.4 Other Government Agency Activities

5.0 STATUS OF BARRIERS TO CCB UTILIZATION

5.1 Barriers Perceived as Unchanged ...

5.2 Summary of Reduction of Barriers

5.3 New Barriers

5.4 Next Steps

6.0 CONCLUSIONS 


\subsection{REFERENCES}

REPORT TO CONGRESS

Appendix A

BARRIERS TO THE INCREASED UTILIZATION OF COAL COMBUSTION/DESULFURIZATION BY-PRODUCTS BY GOVERNMENT AND COMMERCIAL SECTORS $\ldots \ldots \ldots \ldots \ldots \ldots \ldots \ldots \ldots \ldots \ldots \ldots \ldots \ldots \ldots$ Appendix B COAL COMBUSTION BYPRODUCT PRODUCTION \& USE: 1966-1994 … . Appendix C ENVIRONMENTAL FACT SHEET $\ldots \ldots \ldots \ldots \ldots \ldots \ldots \ldots \ldots \ldots \ldots$ Appendix D 